\title{
Factors Affecting Motivation in Language Learning
}

\author{
Hamidah Abdul Rahman, Azizah Rajab, Shah Rollah Abdul Wahab, Faizah Mohd Nor, Wan Zarina \\ Wan Zakaria, and Mohd Asyraf Badli
}

\begin{abstract}
Motivation is one of the fundamental factors in learning a language, the feelings and excitement offered by extra enthusiasm for students to learn a second language in a better way. This study investigated the factors which contribute to motivation in learning English among 80 students of Sekolah Menengah Kebangsaan Lepar Utara. The instrument of the study was a questionnaire adapted from Mohamed Amin, Juriah and Mohd Isa (2001). Findings showed that teachers influence, personal attitude and parental influence do have influence in affecting students' motivation to learn a second language.
\end{abstract}

Index Terms-Motivation, personal attitude, parents influence, teachers influence.

\section{INTRODUCTION}

The English language plays an important role in today's communication society which is continuously increasing as the world rapidly moves towards globalization. Learning a second language assists students in gaining achievements in academic areas [1]. In Malaysia the English language has been taught throughout all levels of education. In primary and secondary schooling, English has been taught for almost 11 years and when the students enter the tertiary level, they still learn English as a subject requirement before graduation. However, despite all of the exposure, the proficiency level of students is subpar.

It is believed that everyone must work together to provide better outcomes for their children, especially parents. Santrock [2] emphasized that the processes of punishment, reinforcement and imitation allow children to inculcate certain behaviours. He explains that when a child is reinforced for an acceptable behaviour, the child is likely to repeat it. Good parenting skills involve a lot of control management [3] The way parents try to control their children will eventually affect their development. It is assumed that the primary role of all parents is to influence, teach and control their children before they go to school. In the learning process, children first imitate their parents or caregivers such as maids who are normally close to them during that period. Observation learning has a significant impact a child's learning language as children observe their parents' use of language at home through the television programmes that they watch or the

Manuscript received February 12, 2016; revised June 27, 2016.

Hamidah Abdul Rahman and Shah Rollah Abdul Wahab are with the Faculty of Management, Universiti Teknologi Malaysia, Malaysia (e-mail: midahp@yahoo.com).

Azizah Rajab, Faizah Mohd Nor, and Wan Zarina Wan Zakaria are with the Language Academy, Universiti Teknologi Malaysia, Johor Bahru Campus, Malaysia.

Mohd Asyraf Badli is with a Secondary School, Kuantan, Pahang, Malaysia. reading material that they read. Family is the only place of learning where the basic framework of personality and development is established [4].

Stott [5] noted pattern of child rearing that promoted positive development. He found that adolescents who came from homes where they were acceptance, mutual confidence and compatibility between parents and children were better adjusted and this resulted in more self-esteem. By providing an environment that supports a child's learning needs at home, parents are involved with their children's learning development. They are able to assist their children at home by using specific learning activities to reinforce the children's work. Psychologists believe that parents have an opportunity to reinforce their children's learning and to influence their general perception towards learning a language [4].

The influence of teachers towards second language teaching within the classroom may affect a students' performance. Research has indicated that many traditional language teaching techniques are extremely ineffective [6]. The use of explicit teaching in areas such as phonology, grammar and vocabulary, seem to be limited in helping learners to notice important inputs. Martinez-Lage [7] mentions that multimedia presentations allow a greater and more effective learning process among learners. Early exposure to a second language also increases a child's capacity to learn. Most learners begin their acquisition process with a silent period in which they speak very little. Wong [8], found that there is a positive correlation and direct relationship between the teacher and a students' English attainment. According to Combs [9], a positive teacher is an essential element in creating a supportive classroom. A self-confident teacher normally displays classroom management behaviour that promotes positive pupils and motivates them towards learning. Teachers who dislike using English may inappropriately encourage non-directive behaviour and be easily diverted from their teaching tasks while being unconcerned with their students' performance. Burns [4] found that teachers who preferred student-centred methods of teaching were more likely to possess a more positive environment rather than traditional approaches. The teachers would influence their students through their teaching philosophy. Some teachers restrict students' talking while others allow talking expression and even interpretation of emotions. Combs [9] stated that, teachers who talk more provide less opportunity for their students to talk and practice their tasks on their own.

Generally, Malaysian students from the normal school system are often passive but good at memorization and rote learning. Most of the time, the language teaching process mainly uses linguistic and logical teaching methods while a limited range of learning and teaching techniques being 
applied. These so-called traditional teaching methods generally rely on chalkboard, talking, book-based teaching, repetition and reinforcement and reviewing sessions ending with comprehensive exams. Throughout the year, students have exams up to 6 or 7 times, just to ensure the students education is according to the syllabus. Although quite a number of the students obtain good grades during lower secondary schooling, they still have problems with communication skills in an English environment. In order to learn English, they need to become active learners.

Good attitude towards learning English is important as it shows that learners are intrinsically motivated to learn. Dornyei and Csizer [10] state that the rate and success of second language attainment is influenced greatly by a learners' second language motivation. Without it, learning a second language might lead to an ineffective grasp of the target language. Woolfolk [11] stated that these motivated children are serious about getting benefits from learning English. They find it interesting to complete English tasks because they really appreciate the learning process. In Malaysia, the students' display poor motivation in learning English regardless of its importance. This is reflected in Parilah's [12] study that examined the views of key informants with regard to their ESL experiences. The study examined the informants' attitudes, motivation and individual characteristics towards ESL. The results showed that even though low achievers recognised the importance of English, they still did not really display a positive attitude towards learning the language. Thus, no motivation was imparted and little effort was spent inside and outside the classroom in order to improve their proficiency.

There are many factors that seem to contribute to motivation in learning a second language such as parental and teachers' influences as well as a students' own attitudes towards English. Hence, this study was conducted to identify which factors affect the Sekolah Menengah Kebangsaan
Lepar Utara students' motivation in learning at second language.

\section{MethodolOGY}

\section{A. Instrument, Sample, Analysis}

The main objective of this study was to determine the factors that contribute to motivation for learning English among 80 out of 101 Form Five students from a rural school in Sekolah Menengah Kebangsaan Lepar Utara situated on the East Coast of Malaysia. This study attempted to identify the students' motivation for learning English with factors such as parental influence, teacher influence and the students' own attitude using a set of questionnaires adapted from Mohamed Amin, Juriah and Mohd Isa [13]. The data was analysed using the Statistical Package for Social Sciences (SPSS) Version 20 for frequency, mean and standard deviation. Score range was divided according to five Likert Scale levels as stated in Table I.

\begin{tabular}{|c|c|c|c|}
\hline Scale & Scale Range & Score & Mean Range \\
\hline 5 & Strongly agree & Highest & $4.50-5.00$ \\
\hline 4 & Agree & High & $3.50-4.49$ \\
\hline 3 & Moderate & Moderate & $2.50-3.49$ \\
\hline 2 & Disagree & Low & $1.50-2.49$ \\
\hline 1 & $\begin{array}{c}\text { Strongly } \\
\text { disagree }\end{array}$ & Lowest & $1.00-1.49$ \\
\hline
\end{tabular}

\section{RESULTS}

The results show in Table II to Table IV.

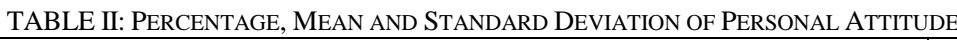

\begin{tabular}{|c|c|c|c|c|c|c|c|}
\hline \multirow{2}{*}{ Statements } & \multicolumn{5}{|c|}{ Distribution on responses $(\%)$} & \multirow{2}{*}{ Mean } & \multirow[t]{2}{*}{ S.D } \\
\hline & SD & D & NAD & $\mathbf{A}$ & SA & & \\
\hline $\begin{array}{l}\text { I am interested in studying } \\
\text { English }\end{array}$ & 0.0 & 5.0 & 27.5 & 55.0 & 12.5 & 3.75 & 0.738 \\
\hline $\begin{array}{l}\text { I practise English every } \\
\text { chance I get. }\end{array}$ & 3.8 & 31.3 & 48.8 & 10.0 & 6.3 & 2.84 & 0.892 \\
\hline $\begin{array}{l}\text { I am not satisfied with my } \\
\text { level of English proficiency }\end{array}$ & 10.0 & 37.5 & 36.3 & 15.0 & 1.3 & 2.60 & 0.908 \\
\hline $\begin{array}{l}\text { I try to watch English TV } \\
\text { shows and movies often }\end{array}$ & 1.3 & 2.5 & 28.7 & 41.3 & 26.3 & 3.89 & 0.871 \\
\hline $\begin{array}{l}\text { I find homework in English } \\
\text { difficult }\end{array}$ & 2.5 & 33.8 & 43.8 & 20.0 & 0.0 & 2.81 & 0.781 \\
\hline
\end{tabular}

Overall Mean = 3.09; minimum $=2.60 ;$ maximum $=3.89 ;$ Range $=1.29$, Average result 3.09 Moderate 
TABLE III: PERCENTAGE, MEAN AND STANDARD DEVIATION OF TEACHER INFLUENCE

\begin{tabular}{|c|c|c|c|c|c|c|c|}
\hline \multirow{2}{*}{ Statements } & \multicolumn{5}{|c|}{ Distribution on responses (\%) } & \multirow{2}{*}{ Mean } & \multirow{2}{*}{ S.D. } \\
\hline & SD & D & NAD & $\mathbf{A}$ & $\mathbf{S A}$ & & \\
\hline $\begin{array}{l}\text { My teacher encourages me to } \\
\text { describe the process orally or in } \\
\text { writing during group discussion }\end{array}$ & 0.0 & 8.8 & 36.3 & 38.8 & 16.3 & 3.63 & 0.862 \\
\hline $\begin{array}{l}\text { My teacher encourages me to use } \\
\text { dictionary in class. }\end{array}$ & 0.0 & 11.3 & 17.5 & 46.3 & 25.0 & 3.85 & 0.929 \\
\hline $\begin{array}{l}\text { My teacher marks my homework } \\
\text { to provide feedback. }\end{array}$ & 0.0 & 5.0 & 48.8 & 35.0 & 11.3 & 3.53 & 0.763 \\
\hline $\begin{array}{l}\text { My teacher provides grammar } \\
\text { games for me to practice } \\
\text { grammar skills. }\end{array}$ & 2.5 & 13.8 & 13.8 & 38.8 & 31.3 & 3.83 & 1.099 \\
\hline $\begin{array}{l}\text { My teacher allows me to discuss } \\
\text { topics with friends }\end{array}$ & 0.0 & 6.3 & 18.8 & 51.2 & 23.8 & 3.93 & 0.823 \\
\hline $\begin{array}{l}\text { My teacher uses ICT to provide } \\
\text { more practice opportunities. }\end{array}$ & 7.5 & 32.5 & 23.8 & 25.0 & 11.3 & 3.0 & 1.158 \\
\hline
\end{tabular}

Overall Mean $=3.63$; minimum $=3.0 ;$ maximum $=3.93$; Range $=0.93$, Average result 3.62 High

SD: Strongly Disagree, D: Disagree, NAD: Neither Agree nor Disagree, A: Agree, SA: Strongly Agree

TABLE IV: Percentage, Mean AND StAndARd DEVIATION OF PARENTAL INFLUENCE

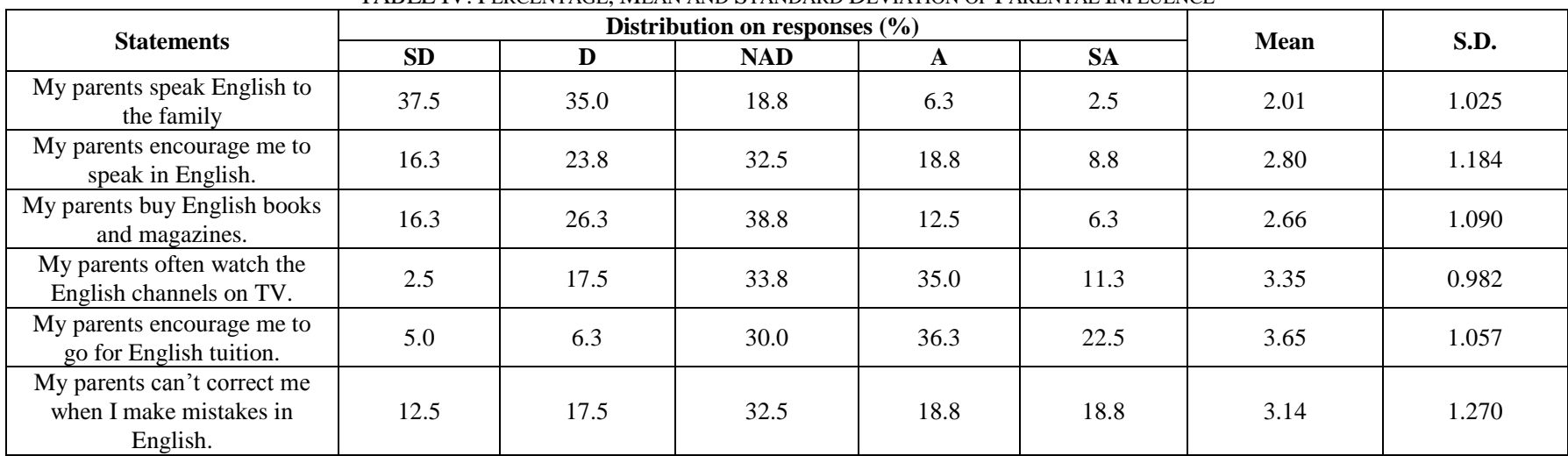

Overall Mean $=2.94 ;$ minimum $=2.01 ;$ maximum $=3.65 ;$ Range $=1.64$, Average result 2.93 Moderate

SD: Strongly Disagree, D: Disagree, NAD: Neither Agree nor Disagree, A: Agree, SA: Strongly Agree

\section{DISCUSSION}

\section{A. Teacher Influence}

The findings indicated that teachers do have a high influence in motivating students in learning English as a Second Language $(m=3.62$, Refer to Table 3). Most of the students agree that the teachers influence is essential, as most teachers encouraged them to learn the language. This proved that the students are highly dependent on their teachers in supporting them learning the language. It revealed that these students have a preference for teacher centred learning. Most of them favour their teachers in giving them opportunities to prepare and discuss work with friends (My teacher allows me to discuss topics with friends). However, teachers in this school did not utilize the ICT as part of their teaching aids, as those facilities or resources were unavailable in the school due to location. Most of the teachers in this school still used discussions as part of their teaching techniques and put into practice using the dictionary as a fun way of studying ( $M y$ teacher encourages me to use dictionary in class). As most teachers who teach English in Malaysian schools are non-native speakers of English, their teaching methods may differ from one another. However, based on the results of this study, even though teachers did not use the ICT to provide more practice opportunities they made up for it by incorporating grammar games to practice grammar obtaining better exposure and improved learning performance among students as they could understand the form and function of the second language. Teachers should endeavor for balance in teaching methods if this is reached, all students will be taught in a manner they prefer leading to increase comfort levels and more willingness to learn. This is in line with what Good \& Brophy [14] believed, in that teachers should provide guidance and assume a supportive role in assisting students' to develop understanding because they have an influence in student's education. In agreement with the findings of this study Sternberg \& William [15] stated that students are not motivated to learn when their teachers resort to traditional methods of teaching. They need to create a positive environment and develop activities that allow students to practice the language in a meaningful context.

\section{B. Personal Attitude}

Based on the findings, most students have a moderate attitude towards the English language $(m=3.09$, Refer to Table II). They realize the importance of learning English in school and they have a desire to learn English (I am interested in studying English), but they feel that learning and practicing English is difficult and stressful and most of them are content with their current proficiency level. However, they still want to improve their English because they try to learn English through interaction and not in a classroom (I try to watch English TV shows and movies often). Thus, despite an overall moderate attitude towards learning English, it would appear that students are actually interested in studying the language. This is consistent with Karahan's [16] study on Turkish EFL students which aimed to determine the relation between 
personal attitudes and language learning. The results showed that the subjects recognized the importance of learning English but did not have high orientation towards learning the language. The subjects had only average positive attitudes towards English learning as they were in tolerant of Turkish people speaking English. Similarly, Starks \& Paltridge [17] stressed that learning a language is closely related to the attitudes towards that language. Karahan [16] also claimed that positive language attitudes let learners have positive orientations towards learning English. As such, attitudes may play a very crucial role as it would determine one's success in language learning. Students with positive attitudes will have better motivation levels and be more successful compared to those with negative attitudes. Therefore, attitude is regarded as one of the key factors that contributes to second language learning achievement as both a positive attitude and motivation need to coexist together in order to achieve a successful language learning experience [18].

\section{Parental Influence}

The results of the study showed that parents have a moderate influence on students' motivation towards learning English as they are also involved in their children's language education ( $\mathrm{m}=2.93$, Refer to Table IV). Even though most parents in this study do not practice much English with students and lack an English environment, parents did motivate students to learn the target language better, even at home. Nevertheless, parents did provide high levels of support by encouraging respondents to go for tuition as they did want their children to learn English and to prepare them for a better future (My parents encourage me to go for English tuition and My parents often watch the English channels on TV). Parents are the first teachers of a student and they take responsibility for their education. They are role models for attitudes and behaviour that could assist in future success, as well as the development of English interests and activities. Students often learn attitudes, cultural morals and values from their parents. The results of this study are similar to a study done by Jeynes [19] which showed that parental involvement is associated with higher student achievement and that it emerged consistently regardless of measures. Academic achievement scores for students whose parents were highly involved in their education were substantially higher than those with less involved parents. Consequently the results of this study is consistent with a study completed by Wong [8] which revealed that factors such as peer influence, parental influence, and a student's own attitudes contribute to English proficiency. This is also contradict with the findings from Paitoonpong's [20] that found teachers had a significant influence on a student's motivation to learn and factors such as a teachers' personality, knowledge, enthusiasm, commitment and classroom management skills have direct influences on learning and motivation.

\section{CONCLUSION}

Based on the study, it was found that teachers have the highest influence on a students' motivation, followed closely by a students' own attitudes towards learning and then parental influence. As teachers are discovered to be the main influence in motivating students' second language learning, they should make an effort to vary their teaching methods and adopt various teaching strategies to attract their students' attention for effective learning. Consequently, students who have positive attitudes towards language learning will be highly motivated and more successful in acquiring the target language. Lastly it is the responsibility of parents to encourage their children to learn, as parents have better opportunities to reinforce learning and give insights into language learning.

\section{REFERENCES}

[1] P. Reich, Language Development, Englewood Cliffs: Prentice-Hall, 1986.

[2] J. W. Santrock, Adolescence, NY: McGraw-Hill, 2003.

[3] D. Baumrind, "The influence of parenting style on adolescent competence and substance use," Journal of Early Adolescence, vol. 11, no. 1, pp. 56-95, 1991.

[4] R.B. Burns, Self-concept Development and Education, Holt: Rinehart and Winston, 1982.

[5] L. H. Stott, "Some family life patterns and their relation topersonality development in children," Journal of Experimental Education, vol. 8, pp. 148-160, 1939

[6] P. Lightbown and N. Spada, How Languages Are Learned, Oxford: Oxford Press, 2006.

[7] A. Martinez-Lage, "Hypermedia technology for teaching reading," in M. Bush \& R. Terry (Eds.), Technology Enhanced Language Learning, Lincolnwood, IL: National Textbook Company, pp. 121-163, 1997.

[8] R. M. H. Wong, "Motivation and English attainment: A comparative study of Hong Kong students with different cultural backgrounds," The Asia Pacific-Education Researcher, vol. 16, no. 1, pp. 45-60, 2007.

[9] A.W. Combs, The Professional Education of Teachers, Boston, Mass: Allyn \& Bacon, 1965.

[10] Z. Dornyei, and K. Csizer, "Ten commandments for motivating language learners: Results of an empirical study," Language Teaching Research, vol. 2, no. 3, pp. 203-229, 1998.

[11] A. Woolfolk, Educational Psychology, Boston, MA: Allyn \& Bacon, 2004.

[12] M.S. Parilah, "Attitude, motivation and individual characteristics as variables of L2 acquisition," Reading in English Language Teaching (ELT), Serdang: Penerbit Universiti Putra Malaysia, pp. 116-123, 2002.

[13] E. Mohamed Amin, L. Juriah, and H. Mohd Isa, "Language and learning strategies employed by secondary school students in Malaysia," Jurnal Pendidikan, vol. 26, Universiti Kebangsaan Malaysia

[14] T. L. Good and J. E. Brophy, Looking in Classroom, New York: Longman, 2000.

[15] R. J. Sternberg and W. M. Williams, Educational Psychology, Boston: Pearson Education Company, 2002.

[16] F. Karahan, "Language attitudes of Turkish students towards the English language and its use in Turkish context," Journal of Arts and Sciences, Cankaya University, Faculty of Arts and Humanities, vol. 7, pp. 73-87, 2007.

[17] D. Starks, B. Paltridge, "A note on using sociolinguistic methods to study non-native attitudes towards English," World Englishes, vol. 15, no. 2, pp. 217-224, 1996.

[18] B. Spolsky, Conditions for Second Language Learning, Oxford: Oxford University Press, 1989.

[19] W. H. Jeynes, "Effects of parental involvement and family structure on the academic achievement of adolescents," Marriage \& Family Review, vol. 37, pp. 99-116, 2005.

[20] F. Paitoonpong, Motivational Variables in Foreign Language Achievement: A Case in Thailand, Singapore: National University Singapore, 1980

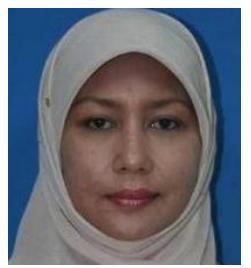

Hamidah Abdul Rahman is a senior lecturer at the Faculty of Management, Universiti Teknologi Malaysia, Johor Bahru Campus. She obtained her Mphil in sociology from Universiti Malaya in 1989. She is currently active in research related to social science and human resource training. 


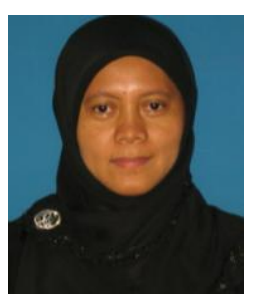

Azizah Rajab is an associate professor at the Language Academy, Universiti Teknologi Malaysia, Johor Bahru Campus. She obtained her $\mathrm{PhD}$ in applied linguistics from Leicester University, United Kingdom in 1996. She is with UTM for more than 27 years and currently active in research related to second language, educational psychology, higher education and social science.

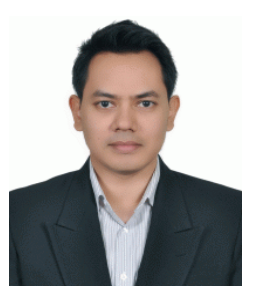

Shah Rollah Abdul Wahab is a senior lecturer at the Faculty of Management, Universiti Teknologi Malaysia, Johor Bahru Campus. He obtained his $\mathrm{PhD}$ in management from Universiti Teknologi Malaysia, Malaysia in 2011. He is with UTM for more than 12 years and currently active in research related to safety management, transformational leadership and employee training.

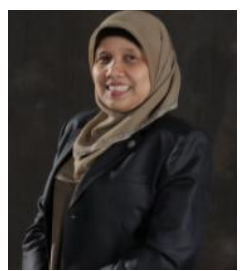

Faizah Mohd Nor is an associate professor at the Language Academy, Universiti Teknologi Malaysia, Johor Bahru Campus. She obtained her PhD in TESL from UTM and has been working with the same institution for more than 21 years and her research include English for specific purposes, teacher training and ELT.

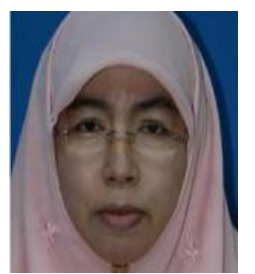

Wan Zarina Wan Zakaria is a senior lecturer at the Language Academy, Universiti Teknologi Malaysia, Johor Bahru Campus. She obtained her MED in curriculum and instruction from Ohio University, USA in 1988. She is with UTM for more than 25 years and currently active in research related to ESL, education psychology, teacher training and literature.

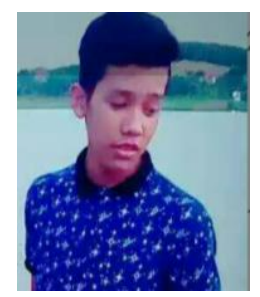

Mohd Asyraf Badli obtained his MEd TESL from Faculty of Education, Universiti Teknologi Malaysia, Johor Bahru Campus in 2013. He is currently teaching at a Secondary School in Kuantan, Pahang and very much interested in research related to motivation, second language learning, ELT and leadership. 